\title{
Role Methods as a Means of Forming the Competence of a Professional
}

\section{Рольові техніки як засіб формування компетентності фахівця}

\section{Zoia Miroshnyk}

Dr. in Psychology, Professor, Kryviy Rih State Pedagogical University, Kryviy Rih, (Ukraine)

ORCID ID: https://orcid.org/0000-0002-3984-6009

Researcher ID: http://www.researcherid.com/rid/R-4082-2018

e-mail: miroshnik@kdpu.edu.us

\section{Зоя Мірошник}

Доктор психологічних наук, професор, Криворізький державний педагогічний університет, м. Кривий Ріг (Україна)

\section{Inna Talash}

Ph.D. in Philology, Assistant Professor, Kryviy Rih State Pedagogical University, Kryviy Rih, (Ukraine)

ORCID ID: https://orcid.org/0000-0002-1208-4729

Researcher ID: http://www.researcherid.com/rid/R-3662-2018 e-mail: inna1talash@gmail.com

\section{Інна Талаш}

Кандидат філологічних наук, доцент, Криворізький державний педагогічний університет, м. Кривий Ріг (Україна)

The author's contribution: Miroshnyk Z. - 50\%, Talash I. - 50\%. Авторський внесок: Мірошник 3. - 50\%, Талаш І. - 50\%.

Address for correspondence, e-mail: kpnu_lab_ps@ukr.net Copyright: (C) Miroshnyk Zoia, Talash Inna

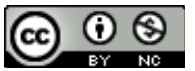

The article is licensed under CC BY-NC 4.0 International (https://creativecommons.org/licenses/by-nc/4.0/)

(C) Miroshnyk Zoia, Talash Inna

DOI (article): https://doi.org/10.32626/2227-6246.2021-52.159-181 


\section{ABSTRACT}

The article presents the characteristics of the structural components of the competence of a specialist of educational institutions, systematizes the methods that contribute to their development.

The purpose of the article is description of role methods aimed at forming the competence of a specialist of an educational institution.

Research methods and techniques. The following methods are used in the research: method of theoretical analysis of scientific literature, synthesis method, constructive method, generalization method.

Results of the research. The list of role methods aimed at development of components of competence, contains both author's methods and modified ones based on K. Levin's field theory and theoretical foundations of the role approach presented in the works of P. Gornostai. In addition, we propose to use roleplaying methods developed and tested within the psychodrama of Ya. Moreno and $A$. Schutzenderger.

The role methods, we have systematized, contribute to the formation of the individual's awareness of his own value and uniqueness ("Dominant roles", "Building the role atom of an individual», "Role regions»); the ability to overcome the negative consequences of the mechanism of alienation that prevails in modern society, to identify the strengths and weaknesses of their personality, integrating them into a holistic self ("Who am I?», "Metaphor»); the ability to overcome stereotypes of behaviour and adjust rigid roles, to identify the role expectations of the subjects of social interaction and to realize their own ("Reconstruction", "Interaction of symbolic representations»); develop spontaneity and creativity (psychodramatic role-playing methods and "Magic Shop»); to form components of role competence (modelling of role situations and psychodramatic method «Pedagogical role play»).

Conclusions. Thus, the proposed methods are only conditionally correlated with certain components of the competence of a specialist as each of them to a greater or lesser extent contributes to the development of all components of competence. Therefore, in our opinion, to achieve the optimal result it is advisable to use the proposed methods in combination, rather than separately.

In further research we plan to develop a program for formation of specialist competence using the proposed role methods.

Key words: competence, components of competence, role competence, role methods, specialist of educational institutions. 


\section{Introduction}

The problem of forming the competence of a modern specialist is associated not only with the transformations in education due to its reform, but also with changes in the personality structure of pedagogues (teachers, lecturers) that occurred under the influence of a number of factors of the social environment such as: declining prestige of the profession; social insecurity; socio-economic and political instability; low general and psychological-pedagogical culture of participants in the educational process; the situation of forced self-isolation in the context of a pandemic. The above factors affect the personality of a professional simultaneously and determine the development of qualities that hinder the professional growth of the specialist and cause the phenomenon of emotional burnout, in particular: low tolerance for frustration, rigidity of thinking, low level of reflection and empathy. Instead, emotional lability increases, while the levels of anxiety, propensity for conflict, uncertainty, and fear heighten.

The low level of resistance of specialists to the negative influences of the social environment can be explained not only by the specialists' individual traits, but also by their weak psychological preparedness for professional activity. In the curricula of institutions of higher education, the number of credits allocated for psychological training of teachers has been disproportionately reduced in recent years in relation to their methodological training. The lack of knowledge in psychology was repeatedly pointed out by experts during a survey we conducted at refresher courses for teachers in the period from 2016 until 2020.

It is obvious that the knowledge of psychology is not enough for an individual to form efficient behaviour patterns that would allow them to adapt quickly to changing conditions and ensure personal and professional growth. It is necessary to seek a specialist's full understanding of the world and man in

(C) Miroshnyk Zoia, Talash Inna

DOI (article): https://doi.org/10.32626/2227-6246.2021-52.159-181 
DOI: https://doi.org/10.32626/2227-6246.2021-52

2021. випУСК 52

it, as emphasized by J. Raven (Равен, 2002), I. V. Yerofeyeva and G. M. Nurullina (Yerofeyeva \& Nurullina, 2017). In addition, it is also necessary to provide appropriate tools for applying the acquired knowledge in practice.

The modern science and practice substantiate the expediency of using techniques that are being developed within the role-playing approach. Their efficiency is due to the fact that professional activity is based on social interaction of diverse hierarchical subordination: teacher-colleague, teacher-representatives of the administration, teacher-student, teacher-student's parents, etc. That interaction is determined by the social status of the entity of interaction and is effected through a respective role. As $\mathrm{P}$. Gornostay points out rightly, the role is both a social function of the individual, a behaviour pattern, a way of assimilating social experience and a way of self-fulfilment, as well as a way of correcting inefficient behaviour patterns (Горностай, 2007).

Within the framework of the role-playing approach, the specifics of inter-entity interaction in certain social or professional groups were revealed most fully and adequately, which provides a sufficient theoretical basis for the development of practical tools to prepare a specialist for successful pedagogical activities. Thus, Z. Miroshnyk offers a development program using role-playing techniques to train students for their future professional activities as primary school teachers (Мірошник, 2011). O. Mykhailenko substantiated and developed a program of psychological and pedagogical support for the development of role-playing competence of the future practicing psychologists (Михайленко, 2018). L. Beheza proves that the role-playing identification is an efficient mechanism for the adaptation of young specialists to their professional activities (Бегеза, 2011). V. Gorbunova developed techniques for the formation and development of teams on the principles of the axiological role approach (Горбунова, 2014).

(C) Miroshnyk Zoia, Talash Inna

DOI (article): https://doi.org/10.32626/2227-6246.2021-52.159-181 
DOI: https://doi.org/10.32626/2227-6246.2021-52

2021. випуск 52

The purpose of the article: description of role-playing techniques aimed at shaping the competence of a specialist of an educational institution.

The task of the article: systematization of role-playing techniques in accordance with the components of the competence of the specialist in the field of education, generalization of psychological conditions of the efficient implementation of those techniques.

\section{Research methods and techniques}

In the study, the method of theoretical analysis of the scientific literature made it possible to identify the role-playing techniques used in practical activities to form the competence of a specialist in the field of education. The synthesis method was used in the process of substantiating the content of the structural components of competence identified by us. The constructive method was used to create proprietary role-playing techniques aimed at the formation and development of certain components of competence. The generalization method was used to draw conclusions on the research done and to formulate prospects for the further research.

Based on the analysis and generalization of the structural components of competence presented in the research of some scientists, in particular of P. Gornostay (Горностай, 2007), I. Zymniaia (Зимняя, 2004), J. Raven (Равен, 2002), J.A. Hagenaars (Hagenaars 2015), J. Kaap-Deeder (Kaap-Deeder, 2018), R. A. Roe (Roe, 2002), L. V. Sadvik (Sadvik, 2019) and others, we identified such components of competence as: 1) the ability to restore authenticity; 2) the ability to identify oneself (capacity for self-identification); 3 ) the ability to conduct a dialogue with the world and with oneself; 4) the ability to be spontaneous and creative; 5) the ability to have a role-playing experience.

The ability to restore authenticity is inherent in a fully independent person who, despite the changing environment,

(C) Miroshnyk Zoia, Talash Inna

DOI (article): https://doi.org/10.32626/2227-6246.2021-52.159-181 
DOI: https://doi.org/10.32626/2227-6246.2021-52

2021. випуск 52

despite being conditioned by the outside world, is able to preserve their own identity. As A. Lenglet points out rightly, authenticity is not constant, since an individual is an open and dynamic system. Therefore the individual is always on the move, in interaction with the outside world borrowing something from it, giving something to it, so there is a need to restore their own authenticity, while remaining capable of maintaining adequate relationships with other people. An authentic individual is able, according to A. Lenglet, to live their own self from the very depth and thus be the self in the full sense of the word (Лэнгле, 2018:64). Consequently, such an individual is able to recognize the uniqueness of another person and, in the process of interaction, take into account those components (values, attitudes, worldviews and motives) that are different from their own worldview ideas. The behaviour of an individual capable of restoring authenticity therefore becomes more efficient, that is, competent.

To restore the authenticity of an individual, it is necessary to feel one's self very clearly, precisely what is intrinsically valuable in it, unique and inimitable, what will be the core under any conditions and circumstances. It is expedient to shape such a feeling in a comfortable situation, when the individual feels safe and can fully focus on identifying their self. Role-playing techniques such as «Dominant Roles», "Building a Role Atom of an Individual» and «Role Regions» can contribute to achieving that goal. Those techniques allow an individual to explore their own role structure, and to determine the axiological roles and prospects of their development through the actualization of their role-playing repertoire.

The «Dominant Roles» technique is aimed at determining the roles that an individual prefers when interacting with their own social environment in certain areas of the life activities: personal, family, social, professional ones. Those areas of life are symbolically denoted as sectors of a circle drawn on a sheet of paper of the A4 size. It should be noted that not all the roles (c) Miroshnyk Zoia, Talash Inna

DOI (article): https://doi.org/10.32626/2227-6246.2021-52.159-181 
that an individual uses as a tool for establishing contact with their environment and for self-fulfilment are obvious and realized by them. In order to obtain more complete information about the roles inherent in the individual, we therefore use a set of metaphorical mind maps. We suggest that the person (the object of the study) focus on a particular sector of the circle and, mentally pronouncing the name of the sector, choose blindly three metaphorical maps that symbolize the roles they most often choose for self-actualization in this particular area of the life activities. Then, we propose them to determine what role, in the opinion of the object of the study, a certain metaphorical map symbolizes. We record those roles in the appropriate sectors of the circle. After that, we analyse, which of those roles are dominant in the sector and why.

The «Building a Role Atom of an Individual» technique was proposed by us on the basis of the method of J. Moreno «Social Atom" (Морено, 2008) that was developed and improved by A. Schutzenberger (Шутценбергер, 2007). A. Schutzenberger gives the following definition of that technique: social atoms are real networks of different shape, compositions and structures endowed with life and real energy that circulates around each individual (Шутценбергер, 2007).

The essence of the technique lies in that a person draws the nucleus of an atom - this is his / her self - while placing around it, in three orbits, people who were or are significant in their life, at the same time indicating whether the interaction with them was positive or negative.

The role atom of an individual consists of the roles that they perform at the current stage of their life: among them there are those that, in the opinion of the person, were mastered by them well enough; those that should be improved, as well as those that are not yet sufficiently mastered or not formed at all, but that need to be mastered for further successful growth (personal or professional). Building the role atom makes it possible to identify the vectors of the forma(C) Miroshnyk Zoia, Talash Inna DOI (article): https://doi.org/10.32626/2227-6246.2021-52.159-181 
DOI: https://doi.org/10.32626/2227-6246.2021-52

2021. випуск 52

tion of the role-playing competence of the individual, and to determine the axiological roles that make up their self. When analysing the role atom of an individual, we pay attention to the arrangement of the roles: whether there are any roles on one conditional axis, which roles are located at the top (these are relevant, most important roles for the individual); at the bottom (roles that have lost or are losing importance for the individual); on the right (roles, which the individual commits their future to); on the left (roles that the individual has mastered well). It is worth analysing separately the roles marked by triangles (the so-called «forgotten roles» that the object of the study did not mark at the outset, but remembered in the middle of the process of analysing or at our suggestion). They usually indicate the presence of a conflict.

The «Role Regions» technique was developed by us based on the ideas generalized in the field theory of $\mathrm{K}$. Lewin, in particular the idea that our life can be conditionally divided into spheres of the life's activities that the famous psychologist suggested calling regions (Левин, 2000). Each region has a dominant role (for example, in the professional region, it is the role of a teacher) that corresponds most accurately to the social status of the person. Regions and roles do not exist in isolation from each other. Otherwise, the individual would not be able to maintain their integrity. The interaction of regions and roles can be of different nature, in particular: conventional one (regions or roles agree with each other, while remaining as autonomous as possible); complementary one (the development of one region or a certain role is a resource for the development of another region, it helps to perform another role more efficiently); confrontational one (the development of one region or a role significantly impedes the development of another region or makes it difficult or even impossible to fulfil another role).

That technique consists in that the object of the study should identify in a circle drawn on a sheet of paper the re(c) Miroshnyk Zoia, Talash Inna

DOI (article): https://doi.org/10.32626/2227-6246.2021-52.159-181 
gions that are the areas of their life activities, give them names and determine for each of them a dominant role. Then, the nature of interaction between the regions is determined, and the prospects of development of a certain region are analysed. We draw the attention of the object of the study to the opportunities that arise in the event of a decrease in the activity in a particular area of life, because it is natural for certain regions to lose their relevance over time (for example, when the composition of the family changes, when children begin to live independently, when changing jobs or the field of professional activity, etc.). The point is that quite often such changes in life are perceived by a person as undesirable, without noticing the new opportunities, new regions that open up thanks to those changes. Of course, such a perception of reality does not contribute to the development of competence, and, as a result, the adaptive potential of the individual decreases.

As the experience of using that technique shows, it is quite difficult for the objects of the study to differentiate their own lives by individual regions and to identify the dominant roles in each of them. It is especially difficult for them to identify promising regions that are still poorly differentiated, so they are not taken into account by the object of the study.

The capacity for self-identification is another important component of competence that directly determines the sense of one's own self. It is the ability to overcome the alienation imposed by the outside world, to recognize the right to exist not only for the strengths and positive aspects of one's own self, but also for the weak, negative ones. This ability provides an individual with the opportunity to live their own life fully, to say «no» to what does not correspond to their moral principles. The capacity for self-identification creates in the individual the personal that regulates, according to A. Lenglet, dissociation and openness, both in the outside world and in relation to what happens within the individual as such (Лэнгле, 2018: 87). The

(c) Miroshnyk Zoia, Talash Inna

DOI (article): https://doi.org/10.32626/2227-6246.2021-52.159-181 
DOI: https://doi.org/10.32626/2227-6246.2021-52

2021. випуск 52

capacity for self-identification therefore conditions the sense of integrity of the individual.

In order to determine the development level of the capacity for self-identification, we suggest using a modified version of the «Semantic Space of the Role-playing Positions of a Specialist» questionnaire (Мірошник, 2011: 274), the «Who am I?» technique modified by Z. Miroshnyk, the «Metaphor» technique proposed by T. Khomulenko and modified by us.

The «Semantic Space of the Role-playing Positions of a Specialist» questionnaire contains a list of actions and deeds that respondents are asked to correlate with certain role-playing positions that they most often have to perform in their professional activities. This technique allows the specialist to structure their own ideas about the content of their professional activities, and to identify the roles that require development and improvement.

The «Who am I?» technique allows individuals to explore their role-playing repertoire, realize valuable roles and reveal the uniqueness of those roles. Along with revealing a unique role in one's role-playing repertoire, a sense of self-worth of the individual is born, an intrapersonal phenomenon emerges, with which a person can identify their own self. It is especially important to feel the value of one's unique self in those situations, where it is necessary to say «no» to the reference person or difficult circumstances.

This technique involves asking the object of the study to write, over five minutes period, 5 to 6 sentences that will answer the question "Who am I?». The object of the study then distinguishes a singular role among the roles listed in the sentences, the unique (or valuable for themselves) one, about which we ask them to write an essay. Describing the unique role, the object of the study realizes its value and finds the origins of the uniqueness of their personality.

The practice of using the "Who am I?" technique enabled us to make the following generalizations: the role-playing (C) Miroshnyk Zoia, Talash Inna

DOI (article): https://doi.org/10.32626/2227-6246.2021-52.159-181 
repertoire of the objects of the study is dominated by social roles; nearly a third part of the objects of the study answering the question «Who am I?» did not give their names. Since the objects of the study, when describing themselves, prefer social roles that are impersonal behaviour patterns generalizing common stereotypes and rules while «forgetting» to give their names, we can say that we observe the action of the mechanism of alienation described in sufficient detail by $\mathrm{H}$. Marcuse as early as the middle of the twentieth century (Маркузе, 2011). While the phenomenon of alienation, a «performance» (G. Debord's term) massively widespread in the modern society, does not greatly affect the quality of the conveyor-belt production, in the field of cultural and spiritual life, the crisis phenomena acquire threatening proportions. In particular, it manifests itself in worsening of the quality of education and training of skilled personnel, in decreasing of the professionalism of specialists, which primarily becomes apparent in the inefficient performance by them of their duties, in lowering of the quality and efficiency of postgraduate training and retraining of specialists.

The phenomenon of a decrease in the efficiency of an individual's behaviour in the social environment, one aspect of which is the deterioration of their capability for creative adaptation, attracted the attention of psychologists as early as the beginning of the twentieth century. In particular, C. Jung noted that the modern individual descends to a state of a mere function, because only that function has a collective value, and only it makes life possible (Юнг, 1996). According to that prominent psychologist, what is threatening is not so much the desire of the society to reduce a person to a certain function that is useful for the collective culture, but the fact that the person themselves begins to identify themselves with that function only rejecting all other functions as unnecessary. In the words of $\mathrm{H}$. Marcuse, a person becomes «unidimensional». As a result, the person who loses that function in the society

(c) Miroshnyk Zoia, Talash Inna DOI (article): https://doi.org/10.32626/2227-6246.2021-52.159-181 
DOI: https://doi.org/10.32626/2227-6246.2021-52

2021. випуск 52

(for example, if they lost their job or were demoted) perceives it as a personal disaster and even loses the sense of their existence. Under such conditions, the need to develop an individual's capacity for self-identification is obvious.

Another technique that, in our opinion, contributes to the development of the capacity for self-identification is the «Metaphor» one. It actually involves searching for a metaphor that reflects the substance of one's professional activities. A metaphor can be a proverb, a saying, an aphorism, etc. It is necessary to draw attention of the object of the study to the emotional colour of the metaphor. For example, when the object of the study described their activities as «Sisyphean's task», we proposed them to replace the phase with a more positive equivalent, in particular «constant dripping wears the stone" focusing on the possibility of personal growth and selfimprovement in a difficult and, at first glance, frustrating situation. If the object of the study finds it difficult to select a metaphor with a positive meaning, you can ask group members to help them. Among the proposed variants of metaphors, it is the object of the study, who chooses the one that appeals to them the most. It should be noted that using a metaphor, one could also describe the nature of the role-playing interaction, for example, teacher-student, teacher-colleague, teacher-administration, etc.

Social intelligence lies at the heart of the ability to conduct a dialogue with the world and with oneself. This ability manifests itself in the ability to reflect, explore the depths of one's own self, accept one's own emotions, qualities and properties, determine one's place in this world, and feel one's own self-worth. At the same time, social intelligence implies the ability to make contact with the reality, to respond adequately to challenges, to take into account the traits of another person in the process of interpersonal interaction, to allow another person to enter their own reality as they are, without trying to put them in the Procrustean bed of their own ideas, as well (C) Miroshnyk Zoia, Talash Inna

DOI (article): https://doi.org/10.32626/2227-6246.2021-52.159-181 
as the ability to change under the influence of circumstances, experience, while maintaining their own integrity and authenticity.

In order to determine the development level of the ability to conduct a dialogue with the world and with oneself, we suggest using a modified version of the "Situational-Role Test» (Miрошник, 2011: 289-291) and the «Reconstruction» technique. The «Situational-Role Test» allows respondents to identify the features of relationships with participants in the educational process (colleagues, parents and students). The content of the test consists of situations, to which response options are required. Depending on which type of response is preferred, the nature of the respondent's interaction with their environment in the professional sphere of activity is determined, according to the key.

The «Reconstruction» technique develops the ability to analyse role-playing interaction, determine role-playing expectations and role-playing stereotypes, as well as the ability to do role-playing decentralization, in particular the ability to think alternatively, see and assess the situation of interpersonal interaction from different role-playing positions. In order to do that, we suggest reconstructing the proposed situation, in particular: to make assumptions regarding the causes of the child's behavior; to determine what information is missing to complete the reconstruction. The situations proposed for consideration include misunderstandings between the parents and the child due to the adults' erroneous misinterpretation of the motives for the child's behaviour that arises because parents are guided by certain stereotypes. In our opinion, it is the development of divergent thinking that enables an individual to make contact with the reality adequately, taking into account the different role-playing positions of the entities of interpersonal interaction, assuming the presence of different roleplaying expectations and motives for the behaviour.

(C) Miroshnyk Zoia, Talash Inna

DOI (article): https://doi.org/10.32626/2227-6246.2021-52.159-181 
DOI: https://doi.org/10.32626/2227-6246.2021-52

2021. випуск 52

In our opinion, the psycho-dramatic «Interaction of Symbolic Representations» technique proposed by A. Schutzenberger (Шутценбергер, 2007:164) will also be appropriate. This technique allows an individual to explore the problems of interdependence of different regions (areas of their lives) and to identify the nature of role-playing interaction in interpersonal relationships. To do that, the protagonist appoints people from the group members who will play the dominant roles of a particular region or a specific person, with whom the protagonist has a strained relationship. By watching the interaction of the performers of certain roles, the protagonist can realize the causes of misunderstandings, conflict situations, or their own role-playing tension.

The ability to be spontaneous and creative is conditioned by the pronounced desire of the individual to play a role, and is manifested in their willingness to explore the world and themselves in the world, gain new experience, experiment in stressful situations (situations of uncertainty, lack of information) with new behaviour patterns, avoid stereotypical thinking, and feel the transience of life.

In order to develop the ability to be spontaneous and creative, J. Moreno and A. Schutzenberger proposed a number of psycho-dramatic techniques. Thus, J. Moreno offers spontaneity training, whose essence lies in the fact that the protagonist loses a number of rigid roles through role-playing regaining in the process the spontaneity that is inherent in a person in the early stages of their ontogenesis (Морено, 2008: 370-372). The development of creativity will also be facilitated by the technique described by A. Schutzenberger, "The Magic Shop» (Шутценбергер, 2007:166-169). This technique, according to the author, not only develops creativity, but also allows an individual to cognize better their self, to reveal personality problems in a symbolic form, and even to touch upon existential problems.

(C) Miroshnyk Zoia, Talash Inna

DOI (article): https://doi.org/10.32626/2227-6246.2021-52.159-181 
The ability to have role-playing experience involves the formation and development of components of role-playing competence, such as role-playing flexibility, role-playing variability, role-playing decentring, and role-playing profundity. In our opinion, it is expedient to regard role-playing competence not as a type of competence, but as its integral component, since just as an individual does not exist outside the social, so they do not exist outside the role-playing activity. As N. Korabliova notes rightly: "The process of role-playing activity is a real historical movement of a person's cognizance of their essential nature in their specifically historical implementation ... the social existence of that person being a constant shift of statuses and roles» (Корабльова, 2000:10). Any interaction therefore takes place within the framework of a role-playing activity, which is reflected in the content of all types of competence. That content is primarily characterized by role-playing positions, such as: addresser-addressee; communicator-recipient, etc. (communicative competence); teacher-student, managersubordinate, etc. (social competence) and so on. In addition, P. Gornostay notes that an individual plays certain roles not only in the process of direct interpersonal interaction, they also have a certain set of internal roles, sometimes imaginary, that determine the features of their interaction with the outside world and ensure a dialogue with themselves (Горностай, 2007).

While training specialists, the development of role-playing competence components will be facilitated by the use of role-playing situations, whose efficiency was substantiated by T. Yablonska (Яблонська, 2012). Modelling role-playing situations allows specialists to acquire the necessary skills to apply theoretical knowledge in pedagogy and psychology in practice and, in addition, to correct inefficient behaviour patterns, as well as to find new ways to resolve conflict situations. In order to determine the development level of the ability to form the desired patterns of behaviour and overcome rigid roles, it is 
DOI: https://doi.org/10.32626/2227-6246.2021-52

2021. випуск 52

advisable to use the «Pedagogical Role Play» technique proposed by A. Schutzenberger (Шутценбергер, 2007: 144-145). The "Pedagogical Role Play" allows professionals not only to overcome rigid roles, but also to cope with situations of frustration acquiring the necessary role-playing competence.

The use of the "Tell Me about Yourself» technique will contribute to the formation of the ability to decentralize. The essence of this technique is that group members are asked to tell in the first person about the object or phenomenon of nature, whose image they blindly pulled out of the set of cards. It is suggested to compose the story according to the following plan: a) I live...; b) my friends...; c) I like when... / that...; d) I am happy when...; e) I am sad when...; f) I would like to...

The «Interpersonal Conflict» technique cultivates the development of the ability to be flexible and variable in role-playing. The members of the group are invited to act out conflict situations that arise between the entities of social interaction due to unjustified role expectations. In the process of performing the technique, the group members are asked to determine the structure and dynamics of the conflict, the causes of its occurrence, and suggest its solution using the theoretical principles of the role-playing approach.

It should be noted that the components of competence listed above are universal for all its types, but their ratio will differ depending on the content of a particular type of competence (some components will be dominant, while others will be secondary). In addition, all components of competence are interconnected and interdependent. Thus, the ability to restore authenticity determines the ability to identify oneself, which, in turn, enables a dialogue of the individual with the world and with themselves. It is obvious that the ability to be spontaneous and creative is directly correlated with other components of competence. 


\section{Conclusions}

Consequently, the mechanisms of alienation inherent in modern society, as well as the low level of psychological culture of the overwhelming majority of specialists, make it necessary to search effective methods for development of personality competence. As social interaction, which underlies the professional activity of an individual, is essentially a role interaction, the use of role methods for development of a specialist's competence seems to be the most optimal. The proposed techniques are only conditionally correlated with certain components of a specialist's competence, since each of them contributes to the development of all components of competence to a greater or lesser extent. In our opinion, in order to achieve the optimum result, it is therefore advisable to use the proposed techniques in combination rather than in isolation.

In further research, we plan to work out the development program for the formation of a specialist's competence using the proposed role-playing techniques.

\section{Literature}

Бегеза Л. Є. Рольова ідентифікація практичного психолога як критерій його адаптованості у професійно-технічному навчальному закладі. Наукові студї із соціальної та політичної психології. 2011. Вип. 28. С. 10-18.

Горбунова В. В. Ціннісно-рольовий підхід у теорії та практиці командотворення. Наукові студї із соціальної та політичної психологї. 2014. Вип. 34. С. 138-150.

Горностай П. П. Личность и роль. Ролевой подход в социальной психологии личности: монография. Киев : Интерпресс ЛТД, 2007. 312 c.

Зимняя И. А. Психология обучения иностранным языкам в школе. Москва : Просвещение, 1991. 222 с.

Корабльова Н. Багатомірність рольової реальності: соціально-філософський аналіз: автореф. дис. ... д-ра філософ. наук: спец. 09.00.03 «Соціальна філософія та філософія історії». Харків, 2000. 37 с.

Левин К. Теория поля в социальных науках. Санкт-Петербург : Сенсор, 2000. 368 c.

(C) Miroshnyk Zoia, Talash Inna

DOI (article): https://doi.org/10.32626/2227-6246.2021-52.159-181 
DOI: https://doi.org/10.32626/2227-6246.2021-52

2021. випУСК 52

Лэнгле A. Person. Экзистенциально-аналитическая теория личности: сборник статей / пер. с нем. С. В. Кривцовой. Москва : Генезис, 2018. 159 c.

Маркузе Г. Критическая теория общества: Избранные труды по философии и социальной критике / пер. с англ. А. А. Юдина. Москва : АСТ; Астрель, 2011. 382 с.

Михайленко О. Ю. Рольова компетентність сучасного психолога: монографія. Кривий Ріг : Криворізький державний педагогічний університет, 2018. 212 с.

Мірошник 3. Рольова структура особистості вчителя початкових класів: монографія. Харків : ХНПУ, 2011. 306 с.

Морено Я. Психодрама / пер. с англ. Г. Пимочкиной, Е. Рачковой. Москва : Психотерапия, 2008. 496 с.

Равен Дж. Компетентность в современном обществе. Москва : КогитоЦентр, 2002. 185 с.

Шутценбергер А. А. Психодрама / пер. с фр. Г. Бутенко, К. Бутенко. Москва : Психотерапия, 2007. 448 с.

Юнг К. Г. Психологические типы / пер. с нем. С. Лорие. Москва : АСТ «Университетская книга», 1996. С. 35-175.

Яблонська Т. Рольові ситуації в системі структурування педагогічного знання в освітньому процесі університету. Обрї̈. 2012. № 2 (35). C. 52-55. URL : http://nbuv.gov.ua/UJRN/obrii_2012_2_18.

Hagenaas, J. A. (2015). Methodological issues categorical data analysis. Categorizatoin, linearity, and response effects. Methodology, 11, 126-141. URL : https://doi.org/10.1027/1614-2241/a000102.

Kaap-Deeder, J., de Houwer, J., Hughes, S., Spruyt, A., \& Vansteenkiste, M. (2018). The development and validation of an implicit measure of competence need satisfaction. Motivation and emotion, 42 (5), 615-637. URL : https://doi.org/10.1007/s11031-018-9685-3.

Roe, R. A. (2002). What makes a competent psychologist? European Psychologist, 7 (1), September, 192-202. URL : https://pdfs.semanticscholar.org/5155/d6004cd4190c39ff00af2ce7dde685bf5539.pdf.

Sandvik, L. V., Solhaug, T., Berg, E. L., Elstad, E., \& Christophersen, K.-A. (2019). Predictions of school mentors' effort in teacher education programmes. URL : https://apps.webofknowledge.com/full_record. do product $=$ WOS\&search_mode $=$ AuthorFinder\&qid $=10 \& S I D=$ C2WSYMbdXPe2skI8Y9D\&page $=1 \&$ doc $=6$.

Yerofeeva, I. V., \& Nurullina, G. M. (2017). The study ancient chronicles within the professional philologist educators' training system. Social and Behavioural Sciences. T. 29. P. 953-960. URL : https:// apps.webofknowledge.com/full_record.do?product=WOS\&search (C) Miroshnyk Zoia, Talash Inna

DOI (article): https://doi.org/10.32626/2227-6246.2021-52.159-181 http://journals.uran.ua/index.php/2227-6246 
DOI: https://doi.org/10.32626/2227-6246.2021-52

2021. ВИПУСК 52

mode $=$ AuthorFinder\&qid $=15 \& S I D=C 2 W S Y M b d X P e 2$ skI8Y9D\&page $=8 \& \mathrm{doc}=75$.

\section{References}

Beheza, L. Ye. (2011). Roliova identyfikatsiia praktychnoho psykholoha yak kryterii yoho adaptovanosti u profesiino-tekhnichnomu zakladi [Role identification of a practical psychologist as a criterion of his adaptability at a vocational school]. Naukovi studii iz sotsialnoi ta politychnoi psykholohii - Scientific studies in social and political psychology, 28, 10-18 [in Ukrainian].

Horbunova, V. V. (2014). Tsinnisno-roliovyi pidkhid u teorii ta praktytsi komandotvorennia [Value-role approach in the theory and practice of team building]. Naukovi studii iz sotsialnoi ta politychnoi psykholohii - Scientific studies in social and political psychology, 34, 138-150 [in Ukrainian].

Hornostai, P. P. (2007). Lichnost $i$ rol. Rolevoi podkhod $v$ sotsianoi psykhologii lichnosti [Personality and role. Role approach to the social psychology of a personality]. Kiiev : Interpress LTD [in Russian].

Zimniaia, I. A. (1991). Psikhologiia obucheniia inostrannym yazykam $v$ shkole [Psychology of teaching foreign languages at school]. Moskva : Prosveshcheniie [in Russian].

Korabliova, N. (2000). Bahatomirnist roliovoi realnosti: sotsialno-filosofskyi analiz [Multidimensionality of role reality: socio-philosophical analysis]. Candidate`s thesis. Kharkiv [in Ukrainian].

Levin, K. (2000). Teoriia polia $v$ sotsialnykh naukakh [Field theory in social sciences]. Sankt-Peterburg : Sensor [in Russian].

Lynhle, A. (2018). Person. Ekzistentsialno-analiticheskaia teoriia lichnosti [Person. Existential-analytical theory of personality]. Moskva : Genezis [in Russian].

Markuze, H. (2011). Kriticheskaia teoriia obshchestva: Izbranniye trudy po filosofii $i$ sotsialnoi kritike [Critical theory of society: Selected works on philosophy and social criticism]. Moskva : AST; Astrel [in Russian].

Mykhailenko, O. Yu. (2018). Roliova kompetentnist suchasnoho psykholoha [Role competence of a modern psychologist]. Kryvyi Rih : Kryvorizkyi derzhavnyi pedahohichnyi universytet [in Ukrainian].

Miroshnyk, Z. (2011). Roliova struktura osobystosti vchytelia pochatkovykh klasiv [Role structure of a personality of a primary school teacher]. Kharkiv : KhNPU [in Ukrainian].

Moreno, Ya. (2008). Psikhodrama [Psychodrama]. Moskva : Psikhoterapiia [in Russian].

(C) Miroshnyk Zoia, Talash Inna

DOI (article): https://doi.org/10.32626/2227-6246.2021-52.159-181 
DOI: https://doi.org/10.32626/2227-6246.2021-52

2021. виПУСК 52

Raven, Dzh. (2002). Kompetentnost $v$ souremennom obshchestve [Competence in modern society]. Moskva : Kogito-Tsentr [in Russian].

Shuttsenberger, A. A. (2007). Psikhodrama [Psychodrama]. Moskva : Psikhoterapiia [in Russian].

Yung, K. G. (1996). Psikhologicheskiie tipy [Psychological types]. Moskva : AST «Universitetskaia kniga» [in Russian].

Yablonska, T. (2012). Roliovi sytuatsii v systemi strukturuvannia pedahohichnoho znannia v osvitniomu protsesi universytetu [Role situations in the system of structuring pedagogical knowledge in the educational process of a university]. Obrii - Horizons, 2 (35), 52-55. Retrieved from http://nbuv.gov.ua/UJRN/obrii_2012_2_18 [in Ukrainian].

Hagenaas, J. A. (2015). Methodological issues categorical data analysis. Categorizatoin, linearity, and response effects. Methodology, 11, 126141. Retrieved from https://doi.org/10.1027/1614-2241/a000102.

Kaap-Deeder, J., de Houwer, J., Hughes, S., Spruyt, A., \& Vansteenkiste, M. (2018). The development and validation of an implicit measure of competence need satisfaction. Motivation and emotion, 42 (5), 615637. Retrieved from https://doi.org/10.1007/s11031-018-9685-3.

Roe, R. A. (2002). What makes a competent psychologist? European Psychologist, 7 (1), 192-202. Retrieved from https://pdfs.semanticscholar.org/5155/d6004cd4190c39ff00af2ce7dde685bf5539.pdf.

Sandvik, L. V., Solhaug, T., Berg, E. L., Elstad, E., \& Christophersen, K.-A. (2019). Predictions of school mentors' effort in teacher education programmes. Retrieved from https://apps.webofknowledge.com/ full_record.do? product $=$ WOS\&search_mode $=$ AuthorFinder\&qid $=$ $10 \& \overline{S I D}=\mathrm{C} 2 \mathrm{WSYMbdXPe} 2 \mathrm{skI} 8 Y 9 D \&$ page $=1 \&$ doc $=6$.

Yerofeeva, I. V., \& Nurullina, G. M. (2017). The study ancient chronicles within the professional philologist educators' training system. Social and Behavioural Sciences, 29, 953-960. Retrieved from https:// apps.webofknowledge.com/full_record.do?product=WOS\&search_ mode $=$ AuthorFinder\&qid $=15 \& S I D=C 2 W S Y M b d X P e 2 s k I 8 Y 9 D \&$ page $=8 \& \mathrm{doc}=75$.

Мірошник Зоя, Талаш Інна. Рольові техніки як засіб формування компетентності фахівця

\section{АНОТАЦІЯ}

у статті подано характеристику структурних компонентів компетентності фрахівця закладів освіти, систематизовано техніки, що сприяють їх розвитку.

(C) Miroshnyk Zoia, Talash Inna

DOI (article): https://doi.org/10.32626/2227-6246.2021-52.159-181 http://journals.uran.ua/index.php/2227-6246 
DOI: https://doi.org/10.32626/2227-6246.2021-52

2021. ВИПУСК 52

Мета статmі - описати рольові техніки, спрямовані на формування компетентності фрахівця закладу освіти.

Методи та методики дослідження. У дослідженні використано метод теоретичного аналізу наукової літератури; метод синтезу; конструктивний метод; метод узагальнення.

Результати дослідження. Перелік рольових технік, спрямованих на розвиток компонентів компетентності, містить як авторські методики, так і модифіковані, що грунтуються на теорії поля К. Левіна і теоретичних засадах рольового підходу, поданих у працях П. Горностая. Крім того, пропонуємо використовувати рольові техніки, розроблені й апробовані в межах психодрами Я. Морено й А. Шутиендергер.

Систематизовані нами рольові техніки сприяють формуванню в особистості: усвідомлення власної цінності й унікальності («Домінантні ролі», «Побудова рольового атому особистості», "Регіони ролі»); уміння долати негативні наслідки механізму відчуження, що панує в сучасному соціумі, виявляти сильні та слабкі сторони своєї особистості, інтегруючи їх у цілісне Я («Я - це хто?», «Метафора»); здатності долати стереотипи поведінки та корегувати ригідні ролі, виявляти рольові очікування суб'єктів соціальної взаємодії й усвідомлювати власні («Реконструкція», «Взаємодія символічних уявлень»); уміння розвивати спонтанність і креативність (психодраматичні техніки рольової гри та "Чарівний магазин»); компонентів рольової компетентності (моделювання рольових ситуацій і психодраматична техніка «Педагогічна рольова гра»).

Висновки. Отже, запропоновані техніки лише умовно співвіднесені з певними компонентами компетентності фахівия, адже кожна з них більшою чи меншою мірою сприяє розвитку всіх складових компетентності. Тому, на нашу думку, для досягнення оптимального результату доцільно запропоновані техніки використовувати в комплексі, а не ізольовано.

У подальших дослідженнях ми плануємо розробити розвивальну програму формування компетентності фахівця з використанням запропонованих рольових технік.

Ключові слова: компетентність, компоненти компетентності, рольова компетентність, рольові техніки, фахівець закладів освіти.

Мирошник Зоя, Талаш Инна. Ролевые техники как средство формирования компетентности специалиста

(C) Miroshnyk Zoia, Talash Inna

DOI (article): https://doi.org/10.32626/2227-6246.2021-52.159-181 


\section{АННОТАЦИЯ}

В статье подана характеристика структурных компонентов специалиста образовательных заведений, систематизированы техники, способствующие их развитию.

Цель статьи - описать ролевые техники, направленные на формирование компетентности специалиста образовательных заведений.

Методы и методики исследования. В исследовании использованы метод теоретического анализа научной литературы; метод синтеза; конструктивный метод; метод обобщения.

Результаты исследования. Перечень ролевых техник, направленных на развитие компонентов компетентности, содержит как авторские методики, так и модифицированные, которые основаны на теории поля К. Левина и теоретических основах ролевого подхода, раскрытых в трудах П. Горностая. Кроме того, предлагаем использовать ролевые техники, разработанные и апробированные в рамках психодрамы Я. Морено и А. Шутценбергер.

Систематизированные нами ролевые техники способствуют формированию у личности: осознания собственной ченности и уникальности ("Доминантные роли», "Построение ролевого атома личности», "Регионы роли»); умения преодолевать негативные последствия механизма отчуждения, который господствует в современном социуме, определять сильные и слабые стороны своей личности, интегрируя их в иелостное Я («Я - это кто?», "Метафора»); способности преодолевать стереотипы поведения и корректировать ригидные роли, определять ролевые ожидания субъектов социального взаимодействия и осознавать собственные ("Реконструкция», "Взаимодействие символических представлений»); умения развивать спонтанность и креативность (психодраматические техники ролевой игры и "Волшебный магазин»); компонентов ролевой компетентности (моделирование ролевых ситуаций и психодраматическая техника «Педагогическая ролевая игра»).

Выводы. Предложенные техники только условно соотносятся с определенными компонентами компетентности специалиста, поскольку каждая из них в большей или меньщей степени способствует развитию всех составляющих компетентности. Поэтому, по нашему мнению, для достижения оптимального результата целесообразно предложенные техники использовать в комплексе, а не изолированно.

(C) Miroshnyk Zoia, Talash Inna

DOI (article): https://doi.org/10.32626/2227-6246.2021-52.159-181 
DOI: https://doi.org/10.32626/2227-6246.2021-52

2021. ВИПУСК 52

В дальнейших исследованиях мы планируем разработать развивающую программу формирования компетентности специалиста с использованием предложенных ролевых техник.

Ключевые слова: компетентность, компоненты компетентности, ролевая компетентность, ролевые техники, специалист образовательных заведений.

Original manuscript received March 12, 2021 Revised manuscript accepted April 18, 2021 